\title{
Leptin: A Correlated Peptide to Papillary Thyroid Carcinoma?
}

\author{
Mehdi Hedayati, ${ }^{1}$ Parichehr Yaghmaei, ${ }^{2}$ Zahra Pooyamanesh, ${ }^{2}$ \\ Marjan Zarif Yeganeh, ${ }^{1}$ and Laleh Hoghooghi Rad ${ }^{1}$ \\ ${ }^{1}$ Obesity Research Center, Research Institute for Endocrine Sciences, Shahid Beheshti University of Medical Sciences, \\ 1985717413 Tehran, Iran \\ ${ }^{2}$ Department of Biology, Faculty of Basic Sciences, Science Research Campus of Islamic Azad University, 1939614484 Tehran, Iran
}

Correspondence should be addressed to Mehdi Hedayati, hedayati@endocrine.ac.ir

Received 25 April 2011; Revised 11 July 2011; Accepted 12 August 2011

Academic Editor: Oliver Gimm

Copyright (C) 2011 Mehdi Hedayati et al. This is an open access article distributed under the Creative Commons Attribution License, which permits unrestricted use, distribution, and reproduction in any medium, provided the original work is properly cited.

Introduction. Leptin as an adipose-tissue-related peptide hormone contributes to the control of food intake, energy expenditure, and other activities such as cell proliferation. Therefore, association of leptin level with thyroid cancer has been suggested recently. Considering that thyroid cancer is the most common endocrine cancer, the aim of this study was evaluation of leptin levels in thyroid cancer. Materials and Methods. 83 patients with papillary thyroid cancer ( 35 males and 48 females) with 90 healthy persons as control group (40 male and 50 females) were selected. serum thyroxine, thyrotropin, and leptin levels were determined in both groups. As a body fat tissue affects leptin level, so height and weight were measured and body mass index was calculated too. Results. There was no statistically significant difference in age, serum Thyroxine, and Thyrotropin levels. BMI in women was more than in men in both groups. Serum leptin levels in thyroid cancer group were significantly higher than control group $(P<0.05)$. Conclusion. The results of this study showed an acceptable association between the hormone Leptin levels with papillary thyroid cancer, so it may be considerad as a correlated peptide which may help in the diagnosis or confirmation of thyroid cancer beside in other specific tumor markers.

\section{Introduction}

leptin with $16 \mathrm{kDa}$ molecular weight mainly produces by white adipose tissue cells [1]. So its level is proportional to the adipose tissue mass [2]. leptin as a neuroendocrine hormone has effects on the glucose metabolism, sexual maturation, reproduction, pituitary-adrenal axis, immune system, thyroid, and growth hormones level [3-6]. The association between this neuroendocrine hormone with obesity and some cancers has been proposed. Probably this hormone is an important risk factor in carcinogenesis, because obesity itself can promote tumorgenesis and is a risk factor for cancer over time $[7,8]$. On the other hand, leptin plays an important role in the oxidation reactions such as fatty acid oxidation [9] and angiogenesis [10]. There are many reports concerning the effect of leptin on stimulation of cell mitosis and its involvement in carcinogenic stages of breast, clone, prostate, lung, kidney, and ovary cells [11-16]. Studies have shown that leptin by increase of cell proliferation and inhibition of apoptosis is involved in creating certain types of tumors [17-19].

leptin acts through its receptor on the cell surface and its receptor expression also increases following the activity of PI3K/AKT pathway and increases the activity of antiapoptosis molecules such as Bcl-XL and XIAP [20]. In some cancer cells, expression of leptin receptor levels and stimulation by leptin will lead to increase of cell proliferation [21]. leptin stimulates expression of some molecules such as CyclinD1, CDK2 and c-Myc that result in cell cycle progression and cell proliferation $[21,22]$.

The Important molecular pathways, such as JAK/STAT3, PI3K/AKT, ERK/MAPK, in many cancer cells can be activated by leptin/leptin receptors [21-24]. Furthermore, leptin with the induction of VEGF and VEGF-R2 molecules expression plays an important role in the tumorigenesis [25]. These molecules are involved in many malignancies such as colon, stomach, endometrial, ovarian, and breast cancer [26-30]. Additionally, increased serum levels of 
leptin and its receptor have been associated with distant metastases, disease recurrence, and lower survival in patients with breast cancer [31]. Increased expression of leptin and its receptor in papillary thyroid cancer has been proved. This hormone probably through its receptor and activation of the PI3K/AKT pathway plays an important role in papillary thyroid cancer pathogenesis. It also seems that the oncogenic effects of leptin on papillary thyroid carcinoma cells are related to the stimulating cell proliferation and apoptosis inhibition. Involvement of thyroid hormones on basal metabolism and regulating appetite and weight control in many scientific reports is given explicitly [10,32-34]. The most common endocrine malignancy is thyroid cancer, and papillary form of thyroid cancer is the most common type of thyroid cancer $(80-90 \%)$ [32]. The aim of this study was determining the serum leptin levels in patients with papillary thyroid cancer and its comparison with healthy subjects.

\section{Materials and Methods}

\subsection{Subjects}

Patients. The case population consisted of 83 individuals, including 35 males and 48 females, 14 to 62 years (mean age 38.6 years) with papillary thyroid cancer (PTC). They were referred to Research Institute for Endocrine Sciences, Shahid Beheshti University of Medical Science. Also, 90 persons were selected as control group (40 male and 50 females) from referred to the laboratory with normal thyroid function tests (TSH: $0.3=3.5 \mathrm{mIU} / \mathrm{L}, \mathrm{T} 4: 4.5=12.5 \mu \mathrm{g} / \mathrm{dL}$, $\mathrm{T}=\mathrm{Up}: 25=35 \%$ and $\mathrm{T} 3: 75=210 \mathrm{ng} / \mathrm{mL}$ ) with age, sex, BMI matched with case group. Both groups were also matched for age and sex. The participants were included in the survey after obtaining an informed consent. Also, the clinical examination was performed by endocrinologist. The diagnosis of PTC was confirmed by histopathologic documents. This study has been approved by Institutional Review Board and Ethics Committee of Obesity Research Center, Research Institute for Endocrine Sciences, Shahid Beheshti University of Medical Sciences.

2.2. Methods. Blood sampling was performed in both studied groups. For preparation of serum, $3 \mathrm{~mL}$ of whole blood was collected from antecubital vein in sitting position and was incubated $10 \mathrm{~min}$ in RT for coagulation. Then sera separated by $10 \mathrm{~min}$ centrifugation at $3000 \mathrm{rpm}$ and the obtained sera were aliquoted in three $0.5 \mathrm{~mL}$ microtubes. The isolated serum samples from each individual were stored in $1 \mathrm{~mL}$ Eppendorf microtubes at $-80^{\circ} \mathrm{C}$ (Japan's Sanyo C Company).

Anthropometric characteristics, including height and weight of patients and control group, were measured by height measuring scaled balance (Seca, German company); height with $0.5 \mathrm{~cm}$ and weight with $250 \mathrm{~g}$ sensitivity were reported. These data were used to calculate the body mass index $\left(\mathrm{kg} / \mathrm{m}^{2}\right)$. Demographic profiles, including age, and sex were also recorded. Those individuals, who were using drugs affecting thyroid function and obesity drugs, were excluded.
In groups thyroxine, thyrotropin, and leptin hormones were measured by ELISA method. The used kits were prepared from the Canadian company (DBC Company, Ontario, Canada). The ELISA reader was from Tecan Austrian Company and Sunrise Model. Human thyrotropin and leptin hormones were determined based on sandwich ELISA method, whereas a thyroxin hormone was measured according to the competitive EIA method. The sensitivity of thyroxine, thyrotropin, and leptin kits was $0.6 \mu \mathrm{g} / \mathrm{dL}$, $0.1 \mathrm{mU} / \mathrm{L}$, and $0.4 \mathrm{ng} / \mathrm{mL}$, respectively. Additionally, the coefficients of variation for these assays were $6.2 \%, 7.1 \%$, and $6.5 \%$, respectively.

2.2.1. Statistical Analysis. According to the normal distribution of data obtained by testing Kolmogorov-Smirnov (KS) $(P=0.68$ for case group and $P=0.52$ for control group), the frequency, mean and standard deviation were used to describe characteristics. All the data were in normal distribution (except leptin after normalization). The independent $t$-test was used to compare mean (except leptin with geometric mean and CI 95\%) of variables between two groups. Comparison of qualitative data was done with Chi-square test. Further, data was analyzed using statistical software (SPSS 15), and significant level was considered at 0.05 .

\section{Results}

Demographic profiles and anthropometric characteristics of participants are provided in Table 1. The results of thyroid hormones test, including thyroxine and thyrotropin in both control and patients groups, are given in Table 2. Since the leptin hormone secreted from adipose tissue is different in male and female, therefore the different levels of measured leptin hormone in two groups are shown in Table 3 (gender based). Height, weight, and body mass index between males and females of both groups were significant $(P<0.05)$. In addition, a significant difference $(P<0.05)$ was observed between the leptin hormone levels in males and females in both healthy and cancer groups. The amount of leptin hormone in cancer patients was higher than that in normal individuals, significantly $(P<0.05)$.

\section{Discussion}

Our data showed that the serum leptin levels of Iranian patients with papillary thyroid carcinoma were significantly higher than those in control group subjects. This increased level was observed in both males and females with papillary thyroid carcinoma. As this increased level was observed in both gender and different ages, so it could be related to thyroid carcinoma and it is independent of sex and age. Even though in this study the leptin level was higher in females than males in both groups, this is probably related to more adipose tissue mass in women. Both leptin and thyroid hormones cause thermogenesis and reduce body weight therefore maybe it is considered as a first association between the two hormones. The hunger reduces the leptin 
TABLE 1: Anthropometric characteristics of participants.

\begin{tabular}{lccccc}
\hline Group & Sex & Height $(\mathrm{cm})$ & Weight $(\mathrm{kg})$ & BMI $\left(\mathrm{kg} / \mathrm{m}^{2}\right)$ & $24.5 \pm 2.3$ \\
\hline \multirow{2}{*}{ Control } & Female $(50)$ & $159.5 \pm 12.1$ & $61.9 \pm 0.3$ & $23.2 \pm 2.0$ & $38.1 \pm 12.5$ \\
& Male (40) & $169.2 \pm 10.5$ & $66.3 \pm 0.2$ & $24.9 \pm 2.7$ & $37.9 \pm 15.8$ \\
Case & Female (48) & $160.2 \pm 11.6$ & $63.7 \pm 0.3$ & $23.7 \pm 2.4$ & $39.1 \pm 13.7$ \\
& Male (35) & $170.4 \pm 11.3$ & $68.4 \pm 0.2$ & $37.5 \pm 17.0$ \\
\hline
\end{tabular}

TABLE 2: Serum levels of thyroxin and thyrotropin hormones in participants.

\begin{tabular}{lcc}
\hline Group & Thyroxin $(\mu \mathrm{g} / \mathrm{dL})$ & Thyrotropin $(\mathrm{mU} / \mathrm{L})$ \\
\hline Control & $9.1 \pm 2.9$ & $2.4 \pm 1.2$ \\
Case & $8.9 \pm 3.0$ & $2.6 \pm 1.0$ \\
\hline
\end{tabular}

TABLE 3: Serum leptin levels in participants.

\begin{tabular}{lll}
\hline Group & $\begin{array}{l}\text { Females serum } \\
\text { leptin level } \\
(\mathrm{ng} / \mathrm{mL})\end{array}$ & $\begin{array}{l}\text { Males serum leptin } \\
\text { level }(\mathrm{ng} / \mathrm{mL})\end{array}$ \\
\hline Control & $4.3 \pm 6.9$ & $2.2 \pm 5.6$ \\
Case & $19.6 \pm 23.3$ & $10.4 \pm 17.3$ \\
$(P<0.05)$ & $(P<0.05)$ \\
\hline
\end{tabular}

and thyroid hormones levels [35]. High levels of thyroid hormones decrease leptin expression in adipose tissue. But the most studies have not shown significant changes in leptin levels in hypothyroidism and hyperthyroidism disorders [36, 37]. However, increased leptin level in postpartum thyroiditis has been reported [38]. Akinci et al. reported that leptin levels increased in papillary thyroid carcinoma in Turkish population [39]. But in their study only 34 cases were investigated, the status of thyroid function in patients and healthy group was not evaluated, and age-matching was not considered [39]. In our study, 83 persons were matched for age, sex, and BMI. Assessing thyroid function in patients and healthy individuals was performed, and no significant difference was observed in both groups.

In both above studies, BMI in women was higher than in men, which was quite predictable. In both studies leptin levels in women were higher than those in men that is because of increased fat mass in women. In one study Cheng et al. showed that expression of leptin and/or leptin receptor in papillary thyroid cancer was associated with neoplasm aggressiveness, including tumor size and lymph node metastasis [40]. Interestingly, in another study, Uddin et al. demonstrated that leptin plays an important role in papillary thyroid cancer pathogenesis through PI3K/AKT pathway via its receptor $(\mathrm{Ob}-\mathrm{R})$ and is a potential prognostic marker associated with an aggressive phenotype and poor survival [32].

One of the limitations of our study was inability to followup the patients after surgery. Therefore, reduction or normalization of high leptin levels in thyroid cancer patients was not assessed. However, a significant increase of serum leptin levels in Iranian patients with papillary thyroid carcinoma maybe used as a reliable marker to diagnose or confirm papillary thyroid cancer. In addition if the leptin levels in cancer patients decrease after thyroidectomy, it will be used for the followup treatment, possibly. So a beforeafter study is recommended for future investigations instead of case control study. Thus, leptin level measurement can be used to followup the treatment of patients.

Strongly high leptin level in papillary thyroid cancer patients in comparison with health subject potentially suggests leptin as a peptide marker of papillary thyroid cancer. It means that adipose tissue secreted hormones, proteins, and peptides potentially may have application in diagnosis, confirmation, and/or treatment followup.

\section{Acknowledgments}

This study was supported by a research grant from Endocrine Research Center, Shahid Beheshti University of Medical Sciences. The authors are indebted to kind collaboration of several endocrinology specialists. They express their gratitude to the staffs of Laboratory at Endocrine Research Center, for their skillful technical assistance.

\section{References}

[1] C. Liu, X. J. Liu, G. Barry, N. Ling, R. A. Maki, and E. B. De Souza, "Expression and characterization of a putative high affinity human soluble leptin receptor," Endocrinology, vol. 138, no. 8, pp. 3548-3554, 1997.

[2] M. Wauters, R. V. Considine, and L. F. Van Gaal, "Human leptin: from an adipocyte hormone to an endocrine mediator," European Journal of Endocrinology, vol. 143, no. 3, pp. 293$311,2000$.

[3] M. W. Schwartz, R. J. Seeley, L. A. Campfield, P. Burn, and D. G. Baskin, "Identification of targets of leptin action in rat hypothalamus," Journal of Clinical Investigation, vol. 98, no. 5, pp. 1101-1106, 1996.

[4] R. S. Ahlma, D. Prabakaran, C. Mantzoros et al., "Role of leptin in the neuroendocrine response to fasting," Nature, vol. 382, no. 6588, pp. 250-252, 1996.

[5] H. F. Escobar-Morreale, F. E. Del Rey, and G. M. De Escobar, "Thyroid hormones influence serum leptin concentrations in the rat," Endocrinology, vol. 138, no. 10, pp. 4485-4488, 1997.

[6] M. J. M. Diekman, J. A. Romijn, E. Endert, H. Sauerwein, and W. M. Wiersinga, "Thyroid hormones modulate serum leptin levels: observations in thyrotoxic and hypothyroid women," Thyroid, vol. 8, no. 12, pp. 1081-1086, 1998.

[7] L. Vona-Davis and D. P. Rose, "Adipokines as endocrine, paracrine, and autocrine factors in breast cancer risk and progression," Endocrine-Related Cancer, vol. 14, no. 2, pp. 189206, 2007. 
[8] D. D. Deo, A. P. Rao, S. S. Bose et al., "Differential effects of leptin on the invasive potential of androgen-dependent and independent prostate carcinoma cells," Journal of Biomedicine and Biotechnology, vol. 2008, no. 1, Article ID 163902, 2008.

[9] J. H. Pinkney, S. J. Goodrick, J. Katz et al., "Leptin and the pituitary-thyroid axis: a comparative study in lean, obese, hypothyroid and hyperthyroid subjects," University of Bristol, Department of Medicine, Bristol Royal Infirmary, Bristol, UK.

[10] H. Y. Park, H. M. Kwon, H. J. Lim et al., "Potential role of leptin in angiogenesis: leptin induces endothelial cell proliferation and expression of matrix metalloproteinases in vivo and in vitro," Experimental and Molecular Medicine, vol. 33, no. 2, pp. 95-102, 2001.

[11] Z. Liu, T. Uesaka, H. Watanabe, and N. Kato, "High fat diet enhances colonic cell proliferation and carcinogenesis in rats by elevating serum leptin," International Journal of Oncology, vol. 19, no. 5, pp. 1009-1014, 2001.

[12] R. Brauner, C. Trivin, M. Zerah et al., "Diencephalic syndrome due to hypothalamic tumour: a model of the relationship between weight and puberty onset," Journal of Clinical Endocrinology and Metabolism, vol. 91, pp. 2467-2473, 2006.

[13] T. Jaffe and B. Schwartz, "Leptin promotes motility and invasiveness in human colon cancer cells by activating multiple signal-transduction pathways," International Journal of Cancer, vol. 123, no. 11, pp. 2543-2556, 2008.

[14] S. N. O’Brien, B. H. Welter, and T. M. Price, "Presence of leptin in breast cell lines and breast tumors," Biochemical and Biophysical Research Communications, vol. 259, no. 3, pp. 695698, 1999.

[15] L. Li, Y. Gao, L. L. Zhang, and D. L. He, "Concomitant activation of the JAK/STAT3 and ERK1/2 signaling is involved in leptin-mediated proliferation of renal cell carcinoma Caki2 cells," Cancer Biology and Therapy, vol. 7, no. 11, pp. 1787$1792,2008$.

[16] R. Ribeiro, A. Araújo, C. Lopes, and R. Medeiros, "Immunoinflammatory mechanisms in lung cancer development: is leptin a mediator?" Journal of Thoracic Oncology, vol. 2, no. 2, pp. 105-108, 2007.

[17] C. Garofalo and E. Surmacz, "Leptin and cancer," Journal of Cellular Physiology, vol. 207, no. 1, pp. 12-22, 2006.

[18] M. R. Hoda, S. J. Keely, L. S. Bertelsen, W. G. Junger, D. Dharmasena, and K. E. Barrett, "Leptin acts as a mitogenic and antiapoptotic factor for colonic cancer cells," British Journal of Surgery, vol. 94, no. 3, pp. 346-354, 2007.

[19] O. O. Ogunwobi and I. L. P. Beales, "The anti-apoptotic and growth stimulatory actions of leptin in human colon cancer cells involves activation of JNK mitogen activated protein kinase, JAK2 and PI3 kinase/Akt," International Journal of Colorectal Disease, vol. 22, no. 4, pp. 401-409, 2007.

[20] S. Uddin, R. Bu, M. Ahmed et al., "Overexpression of leptin receptor predicts an unfavorable outcome in Middle Eastern ovarian cancer," Molecular Cancer, vol. 8, p. 74, 2009.

[21] Q. L. K. Lam, S. Wang, O. K. H. Ko, P. W. Kincade, and L. Lu, "Leptin signaling maintains B-cell homeostasis via induction of Bcl-2 and cyclin D1," Proceedings of the National Academy of Sciences of the United States of America, vol. 107, no. 31, pp. 13812-13817, 2010.

[22] M. Okumura, M. Yamamoto, H. Sakuma et al., "Leptin and high glucose stimulate cell proliferation in MCF-7 human breast cancer cells: reciprocal involvement of PKC- $\alpha$ and PPAR expression,” Biochimica et Biophysica Acta-Molecular Cell Research, vol. 1592, no. 2, pp. 107-116, 2002.

[23] D. L. Morris and L. Rui, "Recent advances in understanding leptin signaling and leptin resistance," American Journal of
Physiology-Endocrinology and Metabolism, vol. 297, no. 6, pp. E1247-E1259, 2009.

[24] Y. Wang, K. K. Kuropatwinski, D. W. White et al., "Leptin receptor action in hepatic cells," Journal of Biological Chemistry, vol. 272, no. 26, pp. 16216-16223, 1997.

[25] R. R. Gonzalez, S. Cherfils, M. Escobar et al., "Leptin signaling promotes the growth of mammary tumors and increases the expression of vascular endothelial growth factor (VEGF) and its receptor type two (VEGF-R2)," Journal of Biological Chemistry, vol. 281, no. 36, pp. 26320-26328, 2006.

[26] M. Koda, M. Sulkowska, L. Kanczuga-Koda, E. Surmacz, and S. Sulkowski, "Overexpression of the obesity hormone leptin in human colorectal cancer," Journal of Clinical Pathology, vol. 60, no. 8, pp. 902-906, 2007.

[27] S. J. Hong, K. W. Kwon, S. G. Kim et al., "Variation in expression of gastric leptin according to differentiation and growth pattern in gastric adenocarcinoma," Cytokine, vol. 33, no. 2, pp. 66-71, 2006.

[28] M. Koda, M. Sulkowska, A. Wincewicz et al., "Expression of leptin, leptin receptor, and hypoxia-inducible factor $1 \alpha$ in human endometrial cancer," Annals of the New York Academy of Sciences, vol. 1095, pp. 90-98, 2007.

[29] M. Ishikawa, J. Kitayama, and H. Nagawa, "Enhanced expression of leptin and leptin receptor (OB-R) in human breast cancer," Clinical Cancer Research, vol. 10, no. 13, pp. 43254331, 2004.

[30] X. Hu, S. C. Juneja, N. J. Maihle, and M. P. Cleary, "LeptinA growth factor in normal and malignant breast cells and for normal mammary gland development," Journal of the National Cancer Institute, vol. 94, no. 22, pp. 1704-1711, 2002.

[31] N. K. Saxena, D. Sharma, X. Ding et al., "Concomitant activation of the JAK/STAT, PI3K/AKT, and ERK signaling is involved in leptin-mediated promotion of invasion and migration of hepatocellular carcinoma cells," Cancer Research, vol. 67, no. 6, pp. 2497-2507, 2007.

[32] S. Uddin, P. Bavi, A. K. Siraj et al., "Leptin-R and its association with $\mathrm{PI} 3 \mathrm{~K} / \mathrm{AKT}$ signaling pathway in papillary thyroid carcinoma," Endocrine-Related Cancer, vol. 17, no. 1, pp. 191-202, 2010.

[33] R. Valcavi, M. Zini, R. Peino, F. F. Casanueva, and C. Dieguez, "Influence of thyroid status on serum immunoreactive leptin levels," Journal of Clinical Endocrinology and Metabolism, vol. 82, no. 5, pp. 1632-1634, 1997.

[34] C. S. Mantzoros, H. N. Rosen, S. L. Greenspan, J. S. Flier, and A. C. Moses, "Short-term hyperthyroidism has no effect on leptin levels in man," Journal of Clinical Endocrinology and Metabolism, vol. 82, no. 2, pp. 497-499, 1997.

[35] G. Légràdi, C. H. Emerson, R. S. Ahima, J. S. Flier, and R. M. Lechan, "Leptin prevents fasting-induced suppression of prothyrotropin-releasing hormone messenger ribonucleic acid in neurons of the hypothalamic paraventricular nucleus," Endocrinology, vol. 138, no. 6, pp. 2569-2576, 1997.

[36] S. Sreenan, J. F. Caro, and S. Refetoff, "Thyroid dysfunction is not associated with alterations in serum leptin levels," Thyroid, vol. 7, no. 3, pp. 407-409, 1997.

[37] R. Seven, "Thyroid status and leptin in Basedow-Graves and multinodular goiter patients," Journal of Toxicology and Environmental Health-Part A, vol. 63, no. 8, pp. 575-581, 2001.

[38] G. Mazziotti, A. B. Parkes, M. Lage, L. D. K. E. Premawardhana, F. F. Casanueva, and J. H. Lazarus, "High leptin 
levels in women developing postpartum thyroiditis," Clinical Endocrinology, vol. 60, no. 2, pp. 208-213, 2004.

[39] M. Akinci, F. Kosova, B. Cetin, S. Aslan, Z. Ari, and A. Cetin, "Leptin levels in thyroid cancer," Asian Journal of Surgery, vol. 32, no. 4, pp. 216-223, 2009.

[40] S.-P. Cheng, C.-W. Chi, C.-Y. Tzen et al., "Clinicopathologic significance of leptin and leptin receptor expressions in papillary thyroid carcinoma," Surgery, vol. 147, no. 6, pp. 847853, 2010. 


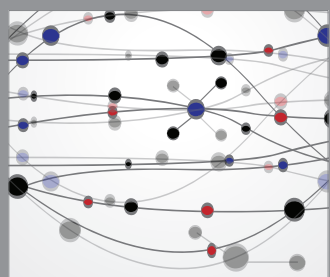

The Scientific World Journal
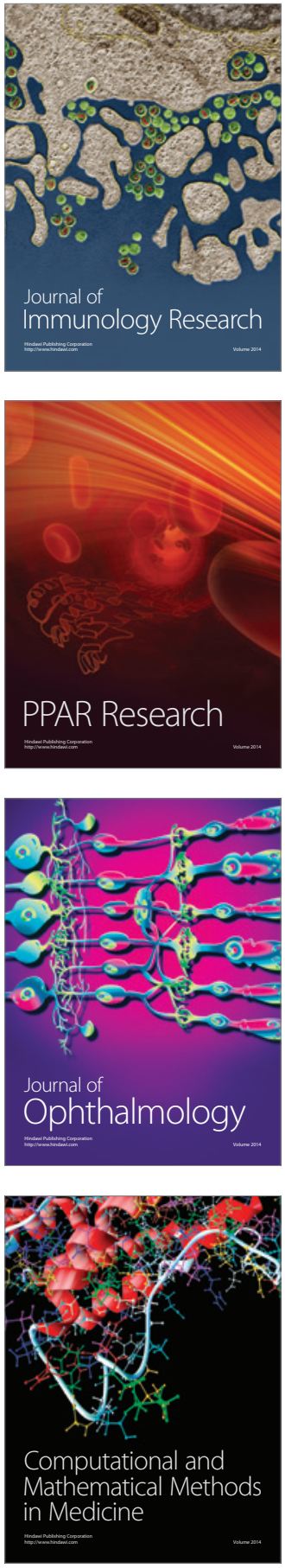

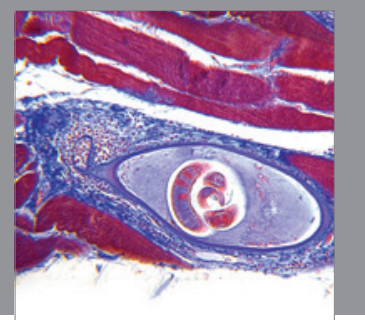

Gastroenterology

Research and Practice
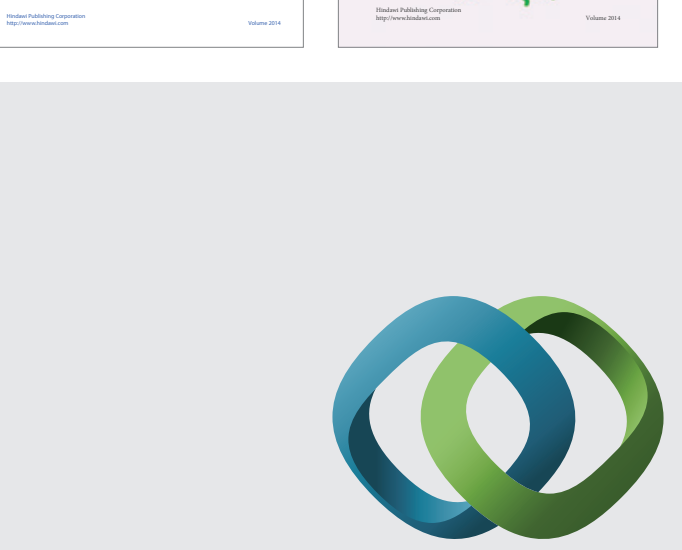

\section{Hindawi}

Submit your manuscripts at

http://www.hindawi.com
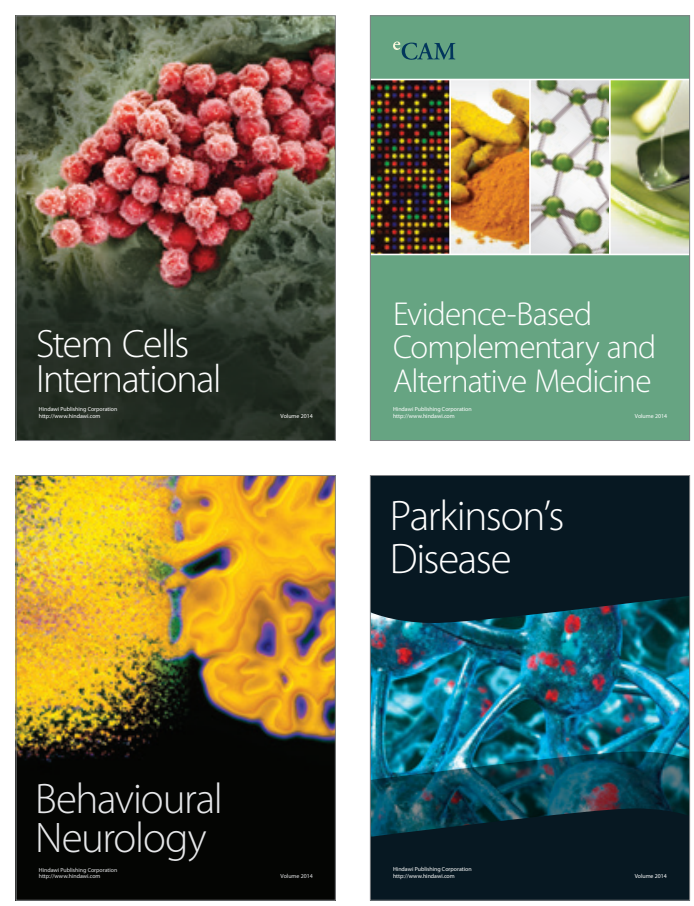

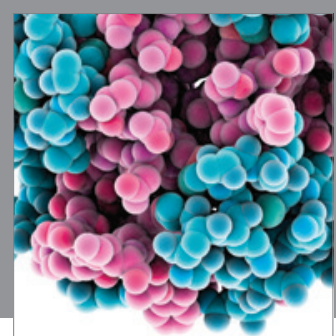

Journal of
Diabetes Research

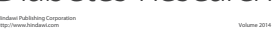

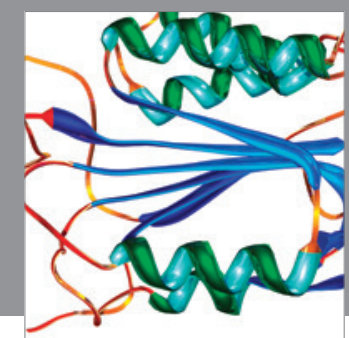

Disease Markers
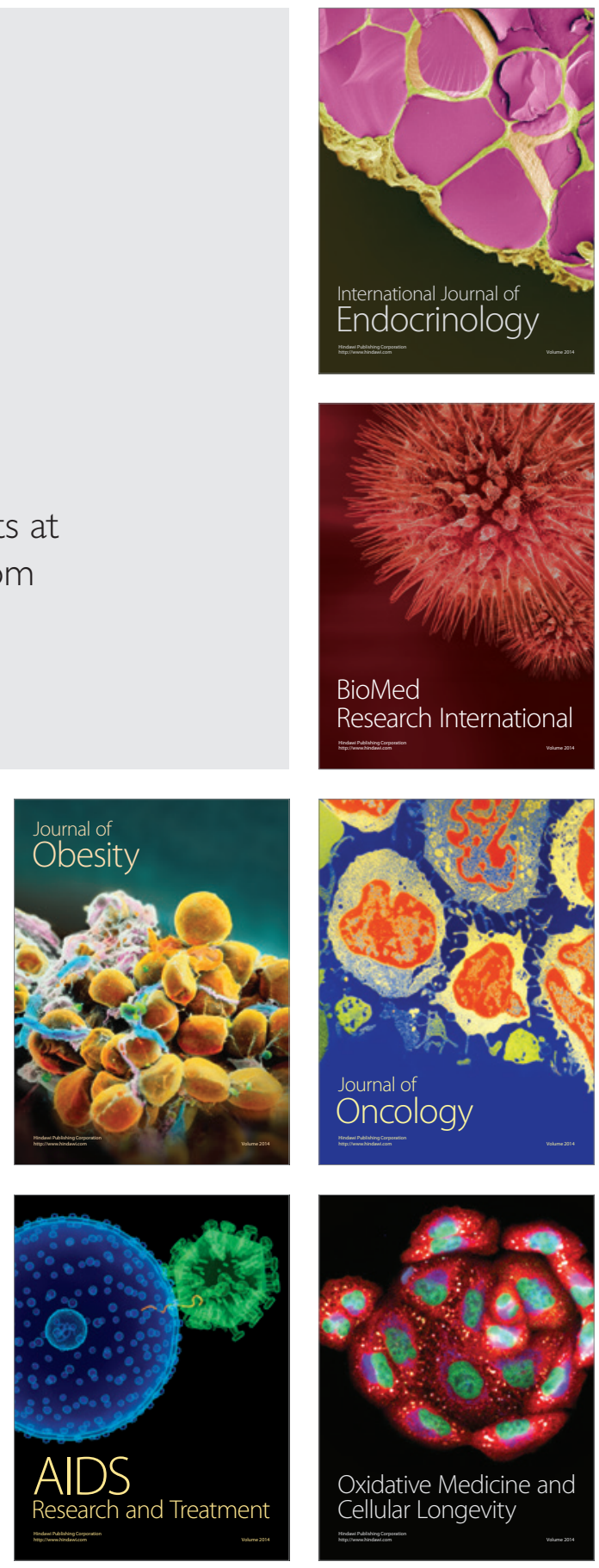